\title{
Effect of Acute $\beta$-blocker Withholding on Ventilatory Efficiency in Patients With Advanced Chronic Heart Failure
}

\author{
PIERANTONIO LAVENEZIANA, MD, ${ }^{1,2}$ PIERGIUSEPPE AGOSTONI, MD, PhD,${ }^{3,4}$ ANDREA MIGNATTI, MD, ${ }^{1}$ \\ SAIMA MUSHTAQ, MD, ${ }^{3}$ PAOLO COLOMBO, MD,${ }^{1}$ DANIEL SIMS, MD, ${ }^{1}$ NIR URIEL, MD,${ }^{1}$ AND ULRICH P. JORDE, MD ${ }^{1}$
}

New York, New York; Florence, Italy; Milan, Italy; Seattle, Washington

\begin{abstract}
Background: This is the first study to examine the effect of acute (24-hour) $\beta$-blocker withholding on ventilatory efficiency in patients with advanced chronic heart failure (CHF) during maximal incremental treadmill cardiopulmonary exercise test.

Methods and Results: Seventeen CHF patients were studied either 3 hours after administration of $\beta$-blocker $\left(\mathrm{BB}_{\mathrm{ON}}\right)$ or 27 hours after the last $\beta$-blocker ingestion $\left(\mathrm{BB}_{\mathrm{OFF}}\right)$. The ventilatory efficiency was measured via the slope of the linear relationship between ventilation $\left(\mathrm{V}_{\mathrm{E}}^{\prime}\right)$ and carbon dioxide production $\left(\mathrm{V}^{\prime} \mathrm{CO}_{2}\right)$ (ie, $\mathrm{V}^{\prime}{ }_{\mathrm{E}} / \mathrm{V}^{\prime} \mathrm{CO}_{2}$ slope). Measurements were also made at rest, anaerobic threshold (AT), maximal end-tidal pressure for carbon dioxide $\left(\mathrm{P}_{\mathrm{ET}} \mathrm{CO}_{2 \mathrm{max}}\right)$, respiratory compensation point $(\mathrm{RC})$, and peak exercise. Compared with $\mathrm{BB}_{\mathrm{ON}}$, the $\mathrm{V}^{\prime}{ }_{\mathrm{E}} / \mathrm{V}^{\prime} \mathrm{CO}_{2}$ slope was significantly increased during $\mathrm{BB}_{\mathrm{OFF}}(30.8 \pm 7.4$ vs. $29.1 \pm 5.4, P=.04)$. At peak exercise, oxygen uptake $\left(\mathrm{V}^{\prime} \mathrm{O}_{2}, 16.0 \pm 2.7\right.$ vs. 15.6 $\pm 2.8 \mathrm{~mL} \cdot \mathrm{kg} \cdot \mathrm{min})$ and $\mathrm{V}^{\prime} \mathrm{CO}_{2}(1458 \pm 459 \mathrm{vs} .1414 \pm 429 \mathrm{~mL} / \mathrm{min})$ were not different between the 2 conditions, whereas $\mathrm{V}_{\mathrm{E}}^{\prime}$ was higher during $\mathrm{BB}_{\mathrm{OFF}}(49.5 \pm 10.7$ vs. $46.1 \pm 9.6 \mathrm{~L} / \mathrm{min}, P=.04)$. No differences were noted at $\mathrm{AT}$ and $\mathrm{RC}$ in $\mathrm{V}^{\prime} \mathrm{O}_{2}, \mathrm{~V}^{\prime} \mathrm{CO}_{2}, \mathrm{~V}_{\mathrm{E}}^{\prime}, \mathrm{V}_{\mathrm{E}}^{\prime} / \mathrm{V}^{\prime} \mathrm{O}_{2}$, and $\mathrm{V}_{\mathrm{E}}^{\prime} / \mathrm{V}^{\prime} \mathrm{CO}_{2}$ ratios during the 2 conditions. At $\mathrm{P}_{\mathrm{ET}} \mathrm{CO}_{2 \max }$, used to noninvasively estimate the $\mathrm{CO}_{2}$ set point, $\mathrm{V}_{\mathrm{E}}^{\prime}$ was higher $(33.9 \pm 7.6$ vs. $31.7 \pm 7.3 \mathrm{~L} / \mathrm{min}, P=.002)$ and $\mathrm{P}_{\mathrm{ET}} \mathrm{CO}_{2}$ was lower $(37.4 \pm 4.8$ vs. $38.5 \pm 4.0 \mathrm{~mm} \mathrm{Hg}, P=.03$ ), whereas $\mathrm{V}^{\prime} \mathrm{CO}_{2}$ was unchanged $(1079 \pm 340$ vs. $1050 \pm 322 \mathrm{~mL} / \mathrm{min})$ during $\mathrm{BB}_{\mathrm{OFF}}$.

Conclusion: Acute $\beta$-blocker withholding resulted in decreased ventilatory efficiency mostly from an increase of $\mathrm{V}^{\prime} \mathrm{CO}_{2}$-independent regulation of $\mathrm{V}_{\mathrm{E}}^{\prime}$ and less likely from a change in ventilation/perfusion mismatching. ( Cardiac Fail 2010;16:548-555)
\end{abstract}

Key Words: $\beta$-blocker, chronic heart failure, ventilatory efficiency, exercise capacity.

The relationship between ventilation and carbon dioxide production (ie, the $\mathrm{V}^{\prime}{ }_{\mathrm{E}} / \mathrm{V}^{\prime} \mathrm{CO}_{2}$ slope) is a measure of ventilatory efficiency and can be used to identify an abnormal ventilatory response to exercise. ${ }^{1,2}$ Patients with chronic

From the ${ }^{1}$ Department of Medicine, Division of Cardiology, Columbia University Medical Center, New York; ${ }^{2}$ Department of Pulmonary Rehabilitation, Fondazione Don C. Gnocchi, Florence, Italy; ${ }^{3}$ Centro Cardiologico Monzino, I.R.C.C.S., Dipartimento di Scienze Cardiovascolari, University of Milan, Milan, Italy and ${ }^{4}$ Division of Critical Care and Respiratory Medicine, Department of Medicine, University of Washington, Seattle, WA.

Manuscript received June 5, 2009; revised manuscript received February 8, 2010; revised manuscript accepted February 10, 2010.

Reprint requests: Professor Ulrich P. Jorde, MD, Medical Director, Cardiac Assist Device Program, Columbia University Medical Center, 622 West 168th Street; PH 12-Stem, New York, NY 10032. E-mail: upj1@ columbia.edu

Pierantonio Laveneziana, MD, pulmonologist, was supported by a Grant from Fondazione Don C. Gnocchi (Department of Pulmonary Rehabilitation), Florence, Italy.

The results of this study were presented, in part, at the European Respiratory Society (ERS) Annual Congress (Vienna, September 2009).

See page 554 for disclosure information.

1071-9164/\$ - see front matter

(c) 2010 Elsevier Inc. All rights reserved.

doi:10.1016/j.cardfail.2010.02.006 heart failure (CHF) often present with an impaired ventilatory response to exercise. ${ }^{2-4}$ In $\mathrm{CHF}$, the $\mathrm{V}_{\mathrm{E}}^{\prime} / \mathrm{V}^{\prime} \mathrm{CO}_{2}$ slope is a strong prognostic marker independent from other exercise related heart failure prognostic markers such as peak oxygen uptake $\left(\mathrm{V}^{\prime} \mathrm{O}_{2}\right)$.,

Long-term treatment with $\beta$-blockers has been shown to reduce the $\mathrm{V}_{\mathrm{E}}^{\prime} / \mathrm{V}^{\prime} \mathrm{CO}_{2}$ slope in patients with $\mathrm{CHF}$ during exercise. ${ }^{6,7}$ Although the precise mechanism(s) underlying this improvement remain to be fully elucidated, amelioration of ventilation/perfusion mismatching, ${ }^{6}$ as well as regulation of the partial arterial pressure of carbon dioxide $\left(\mathrm{PaCO}_{2}\right)$ set point (which is in part controlled by sympathetic nervous system activity ${ }^{7,8}$ ) have been advocated as potential contributory factors. ${ }^{6,7}$

Of note, acute hemodynamic effects of $\beta$-blocking are often deleterious with a fall in ejection fraction and rise in peripheral vascular resistance in patients with $\mathrm{CHF}^{9,10}$ whereas the chronic effect of changes in $\beta$-receptor density ${ }^{11-14}$ may best explain the observed benefits on cardiac structure and clinical outcomes. ${ }^{15,16}$ Indeed, $\beta$-blockers exert many acute and chronic effects on both 
cardiac and noncardiac receptors including ventricular $\beta$-adrenoceptors, ${ }^{12-14}$ as well as chemo-, metabo-, and ergo-receptors in the peripheral muscles indirectly via sympathetic system activation. $^{6-8}$

In principal, the improved ventilatory efficiency seen after long-term treatment could be due to acute as well as chronic effects of $\beta$-blockers. Accordingly, we examined the effect of 24-hour $\beta$-blocker withholding on ventilatory efficiency in patients with advanced CHF during maximal incremental treadmill cardiopulmonary exercise test and compared our data on acute $\beta$-blocker withholding with historical published data on chronic (2-month) $\beta$-blocker withholding from Agostoni and coworkers ${ }^{7}$ to find out whether a unified mechanism could explain the effect of acute and chronic $\beta$-blocker withholding on ventilatory efficiency in CHF patients.

\section{Methods}

\section{Subjects}

All patients with advanced systolic CHF, in New York Heart Association Class II-IV, on stable medical therapy including $\beta$-blockers for at least 3 months referred for cardiopulmonary exercise tolerance testing (CPET) were screened for participation in the study from March 2008 through December 2008. Patients with atrial fibrillation, inability to exercise, hospital admission for heart failure, or acute coronary syndrome in the past 90 days or with symptoms of myocardial ischemia were excluded. Also excluded were patients with other medical conditions, such as respiratory diseases, primary pulmonary hypertension, or neuromuscular and orthopedic diseases, which could cause or contribute to exercise intolerance. The study was approved by the institutional review board of New York Presbyterian Hospital, Columbia University Medical Center. Informed consent was obtained from all participants.

\section{Study Design}

This was a randomized, parallel, crossover study. Each participant performed 2 CPETs at 10 am in the morning conducted 5 to 7 days apart. Subjects were instructed to either take $\beta$-blockers 3 hours before the visit or to withhold $\beta$-blockers following the 7 am dose on the preceding day. Accordingly, 1 test was conducted 3 hours after administration of $\beta$-blocker $\left(\mathrm{BB}_{\mathrm{ON}}\right)$, whereas the other test was performed 27 hours after the last $\beta$-blocker ingestion $\left(\mathrm{BB}_{\mathrm{OFF}}\right) . \mathrm{BB}_{\mathrm{ON}}$ and $\mathrm{BB}_{\mathrm{OFF}}$ visits were performed in random order to eliminate possible training effects. The investigator(s) responsible of performing CPET was not involved in the analysis of the results.

\section{CPET}

During each visit, patients underwent a symptom-limited incremental treadmill CPET. The work rate increased continuously as a ramp function by augmenting the speed and grade of the treadmill according to a modified Naughton protocol. Patients were instructed to exercise until the point of symptom limitation. Patients were strongly encouraged to perform a maximal test, but they determined when their symptoms were so severe that it was necessary to stop exercising. Resting heart rate (HR) was obtained after 30 minutes of rest in a quiet, temperature-controlled room. Electrocardiographic monitoring of HR, rhythm, and ST-segment changes were recorded continuously at rest and throughout exercise testing, whereas blood pressure (by indirect sphygmomanometry) was collected at rest, every 2 minutes during exercise, and upon completion of exercise. Cardiopulmonary and breathing pattern measurements were collected in a breath-by-breath fashion while subjects breathed through a mouthpiece with attached low-resistance flow transducer with nasal passages occluded by a nose clip using a Medgraphics metabolic cart (Medical Graphics Corporation St. Paul, MN). V' ${ }_{E}^{\prime}, \mathrm{V}^{\prime} \mathrm{O}_{2}$, $\mathrm{V}^{\prime} \mathrm{CO}_{2}$, end-tidal oxygen and carbon dioxide partial pressure $\left(\mathrm{P}_{\mathrm{ET}} \mathrm{O}_{2}\right.$ and $\mathrm{P}_{\mathrm{ET}} \mathrm{CO}_{2}$, respectively), tidal volume $\left(\mathrm{V}_{\mathrm{T}}\right)$, and respiratory frequency $(\mathrm{R} f)$ were calculated. Exercise variables were measured continuously and averaged over the last 20 seconds of each minute and at peak exercise, defined as the last 20 seconds of loaded exercise. The instruments were calibrated before every test and were corrected for humidity, room temperature, and barometric pressure, according to the manufacturer's protocol. Peak $\mathrm{V}^{\prime} \mathrm{O}_{2}\left(\mathrm{~V}^{\prime} \mathrm{O}_{2 \text { peak }}\right)$ and peak $\mathrm{V}_{\mathrm{E}}^{\prime}\left(\mathrm{V}_{\text {Epeak }}^{\prime}\right)$ were defined, respectively, as the highest value of $\mathrm{V}^{\prime} \mathrm{O}_{2}$ and $\mathrm{V}_{E}^{\prime}$ that could be sustained for at least 20 seconds during the last stage of exercise when the respiratory exchange ratio (RER) was $>1.0$. Metabolic and cardioventilatory variables were reported according to formulas as previously described. ${ }^{17}$

The anaerobic threshold $(A T)$ was detected individually using the $\mathrm{V}$-slope method and verified against other points; that is, the $\mathrm{V}^{\prime} \mathrm{O}_{2}$ at which the ventilatory equivalent for oxygen $\left(\mathrm{V}_{\mathrm{E}}^{\prime} / \mathrm{V}^{\prime} \mathrm{O}_{2}\right)$ begins to increase systematically without an increase in the ventilatory equivalent for carbon dioxide $\left(\mathrm{V}^{\prime}{ }_{\mathrm{E}} / \mathrm{V}^{\prime} \mathrm{CO}_{2}\right)$ and where $\mathrm{P}_{\mathrm{ET}} \mathrm{O}_{2}$ begins to increase without a decrease in $\mathrm{P}_{\mathrm{ET}} \mathrm{CO}_{2}{ }^{18}$ The respiratory compensation point $(R C)$ was calculated as the point where the slope of the $\mathrm{V}^{\prime}{ }_{\mathrm{E}} / \mathrm{V}^{\prime} \mathrm{CO}_{2}$ relationship started to increase. ${ }^{18}$ The maximal $\mathrm{P}_{\mathrm{ET}} \mathrm{CO}_{2}$ was defined as the highest value of $\mathrm{P}_{\mathrm{ET}} \mathrm{CO}_{2}$ observed during exercise test, between the $A T$ and the $R C$ point, when $\mathrm{P}_{\mathrm{ET}} \mathrm{CO}_{2}$ remains constant. ${ }^{18}$ This was done to evaluate the $\mathrm{CO}_{2}$ set point, which can be noninvasively estimated by the $\mathrm{P}_{\mathrm{ET}} \mathrm{CO}_{2}$ during exercise before the metabolic compensation point is reached. Exercise capacity was assessed by measuring the $\mathrm{V}^{\prime} \mathrm{O}_{2}$ at $A T$ and peak. Mismatching of the heart and lungs was evaluated via the ventilatory efficiency measure $\mathrm{V}_{\mathrm{E}}^{\prime} / \mathrm{V}^{\prime} \mathrm{CO}_{2}$ slope (ie, the slope of the linear relationship between $\mathrm{V}_{\mathrm{E}}^{\prime}$ and $\mathrm{V}^{\prime} \mathrm{CO}_{2}$ from 1 minute after the beginning of loaded exercise to the end of the isocapnic buffering period). ${ }^{18}$ Two blinded experienced readers independently interpreted each test, and the results were averaged.

For statistical analysis purposes, 5 main points were used for evaluation of exercise parameters: 1) pre-exercise rest (baseline), defined as the steady-state period after at least 3 minutes of breathing on the mouthpiece while being at rest before the start of exercise; 2) AT; 3) maximal $\mathrm{P}_{\mathrm{ET}} \mathrm{CO}_{2}$; 4) RC point; and 5) peak exercise.

\section{Statistical Analysis}

Results were expressed as means \pm SD. A $P<.05$ level of statistical significance was used for all analyses. The current study's group responses at different exercise level points during treadmill exercise (baseline, AT, $\mathrm{RC}$, maximal $\mathrm{P}_{\mathrm{ET}} \mathrm{CO}_{2}$, and peak) were compared using paired $t$-tests with appropriate Bonferroni adjustments for multiple comparisons. Comparisons between data from the current study and those from Agostoni et al were made using unpaired $t$-tests. Repeated measurement analysis was not performed because we were interested in treatment effects at specific exercise points/levels rather than in interactions between treatment and time over the course of the exercise test. Pearson correlations were used to establish associations between dependent variables such as peak $\mathrm{V}_{\mathrm{E}}^{\prime}, \mathrm{V}_{\mathrm{E}}^{\prime} / \mathrm{V}^{\prime} \mathrm{CO}_{2}$ slope and ratios, and relevant 
independent variables, such as HR and rest-to-peak difference in $\mathrm{HR}(\Delta \mathrm{HR})$ and any other measured cardiopulmonary variables.

\section{Results}

Subjects' characteristics are summarized in Table 1.

\section{Cardiovascular Response to CPET}

Differences in cardiovascular responses at rest and at peak exercise after $\mathrm{BB}_{\mathrm{OFF}}$ compared with $\mathrm{BB}_{\mathrm{ON}}$ are shown in Table 2. Based on Weber classification of severity, ${ }^{19,20}$ 1 patient presented with $\mathrm{V}^{\prime} \mathrm{O}_{2}$ at $A T>14 \mathrm{~mL} \cdot \mathrm{min} \cdot \mathrm{kg}$ and $\mathrm{V}^{\prime} \mathrm{O}_{2}$ peak $>20 \mathrm{~mL} \cdot \mathrm{min} \cdot \mathrm{kg}$ (Class A, little or no impairment), 9 patients with $\mathrm{V}^{\prime} \mathrm{O}_{2}$ at $A T$ falling between 11 and $14 \mathrm{~mL} \cdot \mathrm{min} \cdot \mathrm{kg}$ and $\mathrm{V}^{\prime} \mathrm{O}_{2}$ peak between 16 and 20 $\mathrm{mL} \cdot \mathrm{min} \cdot \mathrm{kg}$ (Class B, mild-to-moderate impairment), whereas 7 patients presented with $\mathrm{V}^{\prime} \mathrm{O}_{2}$ at $A T$ falling between 8 and $11 \mathrm{~mL} \cdot \mathrm{min} \cdot \mathrm{kg}$ and $\mathrm{V}^{\prime} \mathrm{O}_{2}$ peak between 10 and $16 \mathrm{~mL} \cdot \mathrm{min} \cdot \mathrm{kg}$ (Class $\mathrm{C}$, moderate-to-severe impairment) during $\mathrm{BB}_{\mathrm{OFF}}$. $\mathrm{BB}_{\mathrm{ON}}$ did not affect exercise capacity; $\mathrm{V}^{\prime} \mathrm{O}_{2}$ peak, $\mathrm{V}^{\prime} \mathrm{O}_{2}$ at $A T$ and time to exhaustion were unaffected by $\mathrm{BB}_{\mathrm{ON}}$ (Tables 2, 3). $\mathrm{BB}_{\mathrm{OFF}}$ patients presented at rest with higher HR, by $6 \pm 6$ beats/min $(\sim 8 \%, P=$ .0006), compared with $\mathrm{BB}_{\mathrm{ON}}$ patients, but with no difference in resting $\mathrm{V}^{\prime} \mathrm{O}_{2}$ (Table 2). $\mathrm{BB}_{\mathrm{OFF}}$ patients stopped exercise at higher HR, by $9 \pm 11$ beats/min $(\sim 7-8 \%, P=$ .003 ), but with no difference in peak $\mathrm{V}^{\prime} \mathrm{O}_{2}$ (Table 2). HR and $\mathrm{V}^{\prime} \mathrm{O}_{2}$ values at $A T$, maximal $\mathrm{P}_{\mathrm{ET}} \mathrm{CO}_{2}$, and $R C$ point after $\beta$-blockers withholding compared with $\mathrm{BB}_{\mathrm{ON}}$ are shown in Table 3. Rest-to-peak changes in HR ranged from $50 \pm$ 21 beats/min during $\mathrm{BB}_{\mathrm{OFF}}$ session to $47 \pm 17$ beats $/ \mathrm{min}$ during $\mathrm{BB}_{\mathrm{ON}}$ session.

\section{Ventilatory Response to CPET}

$\beta$-blocker withholding did not affect $\mathrm{V}_{\mathrm{E}}^{\prime}$ at rest, nor at $A T$ or at $R C$ point (Tables 2,3). At peak exercise, $\mathrm{V}_{\mathrm{E}}^{\prime}$ was increased by $3.5 \mathrm{~L} / \mathrm{min}$ (by $7 \%, P=.04$ ) in the presence of no differences in $\mathrm{V}^{\prime} \mathrm{CO}_{2}, \mathrm{~V}_{\mathrm{T}}$, and $\mathrm{R} f$ after $\beta$-blocker

Table 1. Subjects' Characteristics $(n=17)$

\begin{tabular}{lc}
\hline Male:Female & $11: 6$ \\
Age, y & $51 \pm 11$ \\
Height, cm & $170 \pm 11$ \\
Weight, $\mathrm{kg}$ & $86 \pm 21$ \\
Body mass index, $\mathrm{kg} / \mathrm{m}^{2}$ & $30 \pm 6$ \\
LVEF & $23 \pm 8$ \\
ICM & 8 \\
NICM & 9 \\
Carvedilol & 14 \\
Bisoprolol & 1 \\
Metoprolol & 2 \\
Diuretics & 9 \\
Digoxin & 3 \\
ACE inhibitor & 11 \\
ARB & 4 \\
AA & 8 \\
\hline
\end{tabular}

LVEF, left ventricular ejection fraction; ICM, ischemic cardiomyopathy; NICM, nonischemic (idiopathic) cardiomyopathy; ACE inhibitor, angiotensin-converting enzyme inhibitor; $\mathrm{ARB}$, angiotensin receptors blockers; AA, antialdosterone agents.

Values are means \pm SD. withholding compared with $\mathrm{BB}_{\mathrm{ON}}$ (Table 2). Rest-to-peak changes in $\mathrm{V}_{\mathrm{E}}^{\prime}$ ranged from $39.2 \pm 9.5 \mathrm{~L} / \mathrm{min}$ during $\mathrm{BB}_{\mathrm{OFF}}$ session to $35.9 \pm 9.3 \mathrm{~L} / \mathrm{min}$ during $\mathrm{BB}_{\mathrm{ON}}$ session. At maximal $\mathrm{P}_{\mathrm{ET}} \mathrm{CO}_{2}$, which was observed between the $A T$ and the $R C$ point, $\mathrm{V}_{\mathrm{E}}^{\prime}$ was $2.2 \mathrm{~L} / \mathrm{min}$ higher $(P=$ $.002)$ and $\mathrm{P}_{\mathrm{ET}} \mathrm{CO}_{2} 1.1 \mathrm{~mm} \mathrm{Hg}$ lower $(P=.03)$, whereas $\mathrm{V}^{\prime} \mathrm{CO}_{2}$ was not significantly changed after $\beta$-blocker withholding (Table 3).

$\beta$-blocker withholding did also increase the $\mathrm{V}_{\mathrm{E}}^{\prime} / \mathrm{V}^{\prime} \mathrm{CO}_{2}$ slope by $\sim 5-6 \%$, from the average value of $29.1 \pm 5.4$ to the average value of $30.8 \pm 7.4(P=.04)$ (Fig. 1). Based on Arena ventilatory class (VC) system, ${ }^{21} 9$ patients presented with $\mathrm{V}^{\prime}{ }_{\mathrm{E}} / \mathrm{V}^{\prime} \mathrm{CO}_{2}$ slope $\leq 29.9$ (VC I), 6 patients with $\mathrm{V}_{\mathrm{E}}^{\prime} / \mathrm{V}^{\prime} \mathrm{CO}_{2}$ slope between 30.0 and 35.9 (VC II), 1 patient with $\mathrm{V}_{\mathrm{E}}^{\prime} / \mathrm{V}^{\prime} \mathrm{CO}_{2}$ slope between 36.0 and 44.9 (VC III), and 1 patient with $\mathrm{V}_{\mathrm{E}}^{\prime} / \mathrm{V}^{\prime} \mathrm{CO}_{2}$ slope $\geq 45.0$ (VC IV) during $\mathrm{BB}_{\mathrm{OFF}}$. During $\mathrm{BB}_{\mathrm{ON}}, 11$ patients showed a $\mathrm{V}_{\mathrm{E}}^{\prime} / \mathrm{V}^{\prime} \mathrm{CO}_{2}$ slope $\leq 29.9$ (VC I), 4 patients a $\mathrm{V}_{\mathrm{E}}^{\prime} / \mathrm{V}^{\prime} \mathrm{CO}_{2}$ slope between 30.0 and 35.9 (VC II), and 2 patients a $\mathrm{V}_{\mathrm{E}}^{\prime} / \mathrm{V}^{\prime} \mathrm{CO}_{2}$ slope between 36.0 and 44.9 (VC III), whereas no one showed a $\mathrm{V}_{\mathrm{E}}^{\prime} / \mathrm{V}^{\prime} \mathrm{CO}_{2}$ slope $\geq 45.0$ (VC IV).

The ventilatory equivalents for oxygen and carbon dioxide $\left(\mathrm{V}_{\mathrm{E}}^{\prime} / \mathrm{V}^{\prime} \mathrm{O}_{2}\right.$ and $\mathrm{V}_{\mathrm{E}}^{\prime} / \mathrm{V}^{\prime} \mathrm{CO}_{2}$, respectively) were not significantly different during $\mathrm{BB}_{\mathrm{OFF}}$ session compared with $\mathrm{BB}_{\mathrm{ON}}$ session at rest and at peak exercise (Table 2), as well as at $A T\left(\mathrm{~V}_{\mathrm{E}}^{\prime} / \mathrm{V}^{\prime} \mathrm{O}_{2}=30 \pm 7\right.$ vs. $29 \pm 5 ; \mathrm{V}_{\mathrm{E}}^{\prime} / \mathrm{V}^{\prime} \mathrm{CO}_{2}=32$ \pm 7 vs. $32 \pm 5$ ), and at $R C$ point $\left(\mathrm{V}^{\prime}{ }_{\mathrm{E}} / \mathrm{V}^{\prime} \mathrm{O}_{2}=34 \pm 11 \mathrm{vs}\right.$. $32 \pm 7 ; \mathrm{V}_{\mathrm{E}}^{\prime} / \mathrm{V}^{\prime} \mathrm{CO}_{2}=33 \pm 8$ vs. $32 \pm 6$ ) (Table 3). No differences were also found in $\mathrm{P}_{\mathrm{ET}} \mathrm{O}_{2}$ and $\mathrm{P}_{\mathrm{ET}} \mathrm{CO}_{2}$ values at the previously mentioned levels of exercise in both sessions. Both $\mathrm{V}_{\mathrm{E}}^{\prime} / \mathrm{V}^{\prime} \mathrm{O}_{2}$ and $\mathrm{V}_{\mathrm{E}}^{\prime} / \mathrm{V}^{\prime} \mathrm{CO}_{2}$ ratios were $\sim 2$ units higher during $\mathrm{BB}_{\mathrm{OFF}}$ sessions at maximal $\mathrm{P}_{\mathrm{ET}} \mathrm{CO}_{2}$ because of the higher $\mathrm{V}_{\mathrm{E}}^{\prime}$ at this level of exercise (Table 3).

\section{Correlates of Improvement}

The difference $(\Delta)$ in peak HR between $\mathrm{BB}_{\mathrm{OFF}}$ and $\mathrm{BB}_{\mathrm{ON}}$, an indicator of sinoatrial $\beta_{1}$-receptor blockade, ${ }^{22}$ did not correlate with the $\Delta$ in $\mathrm{V}^{\prime}{ }^{\prime} / \mathrm{V}^{\prime} \mathrm{CO}_{2}$ slope between $\mathrm{BB}_{\mathrm{OFF}}$ and $\mathrm{BB}_{\mathrm{ON}}(r=-0.27, P=.3$ ) (Fig. $2 \mathrm{~A}$ ), nor with the $\Delta$ in peak $\mathrm{V}_{\mathrm{E}}^{\prime}$ between $\mathrm{BB}_{\mathrm{OFF}}$ and $\mathrm{BB}_{\mathrm{ON}}(r=-0.23$, $P=.4)$ (Fig. 2B). The $\Delta$ peak HR did not correlate with $\Delta$ peak $\mathrm{V}^{\prime} \mathrm{O}_{2}$, expressed either as $\mathrm{mL} / \mathrm{min}(r=0.25, P=$ .3) or as $\mathrm{mL} \cdot \mathrm{kg} \cdot \min (r=0.31, P=.2)$. The $\Delta$ peak $\mathrm{V}_{\mathrm{E}}^{\prime}$ and $\Delta \mathrm{V}^{\prime}{ }_{\mathrm{E}} / \mathrm{V}^{\prime} \mathrm{CO}_{2}$ slope correlated both with $\Delta$ peak $\mathrm{P}_{\mathrm{ET}}$ $\mathrm{CO}_{2}(r=-0.826, P=.00004$ and $r=-0.791, P=$ .0002 , respectively). Of note, the $\Delta \mathrm{V}^{\prime}{ }_{\mathrm{E}} / \mathrm{V}^{\prime} \mathrm{CO}_{2}$ slope also correlated with $\Delta$ maximal $\mathrm{P}_{\mathrm{ET}} \mathrm{CO}_{2}(r=-0.64, P=$ .007), and $\Delta \mathrm{V}_{\mathrm{E}}^{\prime}$ measured at maximal $\mathrm{P}_{\mathrm{ET}} \mathrm{CO}_{2}$ correlated with $\Delta$ maximal $\mathrm{P}_{\mathrm{ET}} \mathrm{CO}_{2}(r=-0.56, P=.03)$ (Fig. 3A, B). The $\Delta \mathrm{V}^{\prime}{ }_{\mathrm{E}} / \mathrm{V}^{\prime} \mathrm{CO}_{2}$ slope did not correlate with $\Delta$ peak $\mathrm{V}^{\prime} \mathrm{O}_{2}$, expressed either as $\mathrm{mL} / \mathrm{min}(r=-0.38, P=.1)$ or as $\mathrm{mL} \cdot \mathrm{kg} \cdot \min (r=-0.46, P=.06)$.

\section{Comparison with Historical Controls}

We decided to compare our data on acute $\beta$-blocker withholding with historical published data on chronic (2-month) 
Table 2. Metabolic and Cardiorespiratory Responses to CPET in CHF Patients $(\mathrm{n}=17)$ with $(\mathrm{BB}$ ON $)$ and without $\beta$-blockers $\left(\mathrm{BB}_{\mathrm{OFF}}\right)$

\begin{tabular}{|c|c|c|c|c|}
\hline \multirow[b]{2}{*}{ Variables } & \multicolumn{2}{|c|}{ Rest } & \multicolumn{2}{|c|}{ Peak } \\
\hline & $\mathrm{BB}_{\mathrm{OFF}}$ & $\mathrm{BB}_{\mathrm{ON}}$ & $\mathrm{BB}_{\mathrm{OFF}}$ & $\mathrm{BB}_{\mathrm{ON}}$ \\
\hline Time, seconds & - & - & $953 \pm 188$ & $967 \pm 162$ \\
\hline $\mathrm{V}^{\prime} \mathrm{O}_{2}, \mathrm{~mL} / \mathrm{min}$ & $308 \pm 101$ & $280 \pm 75$ & $1391 \pm 460$ & $1342 \pm 393$ \\
\hline $\mathrm{V}^{\prime} \mathrm{O}_{2} / \mathrm{kg}$ & $3.6 \pm 0.8$ & $3.4 \pm 1.1$ & $16.0 \pm 2.7$ & $15.6 \pm 2.8$ \\
\hline $\mathrm{V}^{\prime} \mathrm{CO}_{2}, \mathrm{~mL} / \mathrm{min}$ & $262 \pm 85$ & $255 \pm 92$ & $1458 \pm 459$ & $1414 \pm 429$ \\
\hline RER & $0.85 \pm 0.06$ & $0.90 \pm 0.1$ & $1.1 \pm 0.1$ & $1.1 \pm 0.1$ \\
\hline $\mathrm{HR}$, beats/min (\% pred) & $73 \pm 13(44 \pm 9)$ & $67 \pm 13^{*}(40 \pm 8)^{*}$ & $123 \pm 18(73 \pm 10)$ & $114 \pm 16^{*}(68 \pm 9)^{*}$ \\
\hline $\mathrm{O}_{2}$ pulse, $\mathrm{mL} /$ beat & $4.4 \pm 2.2$ & $4.3 \pm 1.6$ & $11.3 \pm 3.1$ & $11.9 \pm 3.5$ \\
\hline $\mathrm{V}_{\mathrm{E}}^{\prime}, \mathrm{L} / \mathrm{min}$ & $10.3 \pm 2.8$ & $10.2 \pm 3.8$ & $49.5 \pm 10.7$ & $46.1 \pm 9.6^{*}$ \\
\hline $\mathrm{R} f$ (breaths/min) & $19 \pm 6$ & $17 \pm 6$ & $38 \pm 9$ & $37 \pm 10$ \\
\hline $\mathrm{V}_{\mathrm{T}}, \mathrm{L}$ & $0.59 \pm 0.23$ & $0.64 \pm 0.29$ & $1.34 \pm 0.32$ & $1.32 \pm 0.37$ \\
\hline $\mathrm{V}_{\mathrm{E}}^{\prime} / \mathrm{V}^{\prime} \mathrm{O}_{2}$ ratio & $34 \pm 6$ & $36 \pm 8$ & $38 \pm 14$ & $36 \pm 11$ \\
\hline $\mathrm{V}_{\mathrm{E}}^{\prime} / \mathrm{V}^{\prime} \mathrm{CO}_{2}$ ratio & $40 \pm 7$ & $41 \pm 7$ & $36 \pm 10$ & $34 \pm 8$ \\
\hline $\mathrm{P}_{\mathrm{ET}} \mathrm{O}_{2}$ & $108 \pm 7$ & $108 \pm 8$ & $113 \pm 9$ & $112 \pm 7$ \\
\hline $\mathrm{P}_{\mathrm{ET}} \mathrm{CO}_{2}$ & $34.4 \pm 3.0$ & $34.1 \pm 3.5$ & $34.1 \pm 6.4$ & $35.2 \pm 4.7$ \\
\hline
\end{tabular}

$\mathrm{CPET}$, cardiopulmonary exercise tolerance testing; $\mathrm{CHF}$, chronic heart failure; $\mathrm{BB}_{\mathrm{ON}}, 3$ hours after administration of $\beta$-blocker; $\mathrm{BB}_{\mathrm{OFF}} 27$ hours after the last $\beta$-blocker ingestion; $\mathrm{V}^{\prime} \mathrm{O}_{2}$, oxygen uptake; $\mathrm{V}^{\prime} \mathrm{CO}_{2}$, carbon dioxide production; RER, respiratory exchange ratio; $\mathrm{HR}$, heart rate; $\mathrm{V}_{\mathrm{E}}^{\prime}$, ventilation; $\mathrm{R} f$, respiratory frequency; $\mathrm{V}_{\mathrm{T}}$, tidal volume; $\mathrm{P}_{\mathrm{ET}} \mathrm{O}_{2}$, end-tidal partial pressure for oxygen; $\mathrm{P}_{\mathrm{ET}} \mathrm{CO}_{2}$, end-tidal partial pressure for carbon dioxide.

Values are means $\pm \mathrm{SD}$.

$* P<.05$.

$\beta$-blocker withholding ${ }^{7}$ to find out whether a unified mechanism could explain the effect of acute and chronic $\beta$-blocker withholding on ventilatory efficiency in $\mathrm{CHF}$ patients.

We compared data of 14 of the 17 subjects of the present experiment who were on carvedilol with historical and previously published data of $8 \mathrm{CHF}$ patients who were studied after chronic (2-month) $\beta$-blocker withholding by Agostoni and coworkers (Fig. 1, Group B, from reference 7). Indeed, we had access and reanalyzed the Agostoni et al data to evaluate only those patients who had prolonged (2-month) $\beta$-blocker withdrawal. Therefore, the 14 patients of the present study were comparable with $8 \mathrm{CHF}$ patients on carvedilol provided by Agostoni and coworkers (Fig. 1, Group $\mathrm{B}$, from reference 7).

Our patients were well matched to Agostoni's cohort with respect to age ( $49 \pm 8$ vs. $50 \pm 9$, respectively, $P=$ $.8)$, peak $\mathrm{V}^{\prime} \mathrm{O}_{2}(15.9 \pm 3.0$ vs. $16.5 \pm 3.8$, respectively, $P$ $=.7)$, peak HR $(72 \pm 11$ vs. $78 \pm 15 \%$ predicted, respectively, $P=.4)$, peak $\mathrm{V}_{\mathrm{E}}^{\prime}(49.6 \pm 9.9$ vs. $45.5 \pm 14.5$, respectively, $P=.5)$, and $\mathrm{V}_{\mathrm{E}}^{\prime} / \mathrm{V}^{\prime} \mathrm{CO}_{2}$ slope $(31.6 \pm 7.9 \mathrm{vs}$. $30.6 \pm 3.9$, respectively, $P=.7$ ) in the $\mathrm{BB}_{\mathrm{OFF}}$ condition, as well as in the $\mathrm{BB}_{\mathrm{ON}}$ condition (peak $\mathrm{V}^{\prime} \mathrm{O}_{2}=15.5 \pm$ 2.9 vs. $17.7 \pm 7.1$, respectively, $P=.4$; peak $\mathrm{HR}=68$ \pm 10 vs. $72 \pm 16 \%$ predicted, respectively, $P=.6$; peak $\mathrm{V}_{\mathrm{E}}^{\prime}=45.8 \pm 8.6$ vs. $43.6 \pm 19.2$, respectively, $P=.8$ ), and $\mathrm{V}_{\mathrm{E}}^{\prime} / \mathrm{V}^{\prime} \mathrm{CO}_{2}$ slope $=29.4 \pm 5.9$ vs. $26.8 \pm 3.8$, respectively, $P=.2$ ). When analyzing both groups separately or in combination, the difference $(\Delta)$ in peak HR between $\mathrm{BB}_{\mathrm{OFF}}$ and $\mathrm{BB}_{\mathrm{ON}}$ did not correlate with the $\Delta$ in $\mathrm{V}_{\mathrm{E}}^{\prime} /$ $\mathrm{V}^{\prime} \mathrm{CO}_{2}$ slope between $\mathrm{BB}_{\mathrm{OFF}}$ and $\mathrm{BB}_{\mathrm{ON}}$, nor with the $\Delta$ in peak $\mathrm{V}_{\mathrm{E}}^{\prime}$ between $\mathrm{BB}_{\mathrm{OFF}}$ and $\mathrm{BB}_{\mathrm{ON}}$ (Fig. 4A, B). The $\Delta$ peak HR did not correlate with $\Delta$ peak $\mathrm{V}^{\prime} \mathrm{O}_{2}$, expressed either as $\mathrm{mL} / \mathrm{min}$ or as $\mathrm{mL} \cdot \mathrm{kg} \cdot \min (r=0.19, P=.4$ and $r=0.28, P=.2$, respectively). The $\Delta$ peak $\mathrm{V}_{\mathrm{E}}^{\prime}$ and
$\Delta \mathrm{V}^{\prime}{ }_{\mathrm{E}} / \mathrm{V}^{\prime} \mathrm{CO}_{2}$ slope correlated both with $\Delta$ peak $\mathrm{P}_{\mathrm{ET}} \mathrm{CO}_{2}$ $(r=-0.82, P=.000003$ and $r=-0.73, P=.0001$, respectively). Of note, the $\Delta \mathrm{V}^{\prime}{ }_{\mathrm{E}} / \mathrm{V}^{\prime} \mathrm{CO}_{2}$ slope also correlated with $\Delta$ maximal $\mathrm{P}_{\mathrm{ET}} \mathrm{CO}_{2}(r=-0.55, P=.01)$. The $\Delta \mathrm{V}^{\prime}{ }_{\mathrm{E}}^{\prime}$ $\mathrm{V}^{\prime} \mathrm{CO}_{2}$ slope did not correlate with $\Delta$ peak $\mathrm{V}^{\prime} \mathrm{O}_{2}$, expressed either as $\mathrm{mL} / \mathrm{min}$ or as $\mathrm{mL} \cdot \mathrm{kg} \cdot \min (r=-0.07, P=.7$ and $r=-0.01, P=.9$, respectively).

\section{Discussion}

The main findings of this study are as follows. 1) Acute $\beta$-blocker withholding worsened ventilatory efficiency in $\mathrm{CHF}$ patients during exercise; 2 ) acute $\beta$-blocker withholding did not modify the ventilation/perfusion mismatching during exercise; 3 ) acute $\beta$-blocker withholding was associated with an increase of reflex regulation of $\mathrm{V}_{\mathrm{E}}^{\prime}\left(\mathrm{V}^{\prime} \mathrm{CO}_{2^{-}}\right.$ independent); and 4) correlative analysis did not show an association between change in peak $\mathrm{HR}$ and change in peak $\mathrm{V}_{\mathrm{E}}^{\prime}$ or in $\mathrm{V}_{\mathrm{E}}^{\prime} / \mathrm{V}^{\prime} \mathrm{CO}_{2}$ slope.

Based on Weber classification of severity, ${ }^{19,20}$ our patients with advanced CHF demonstrated mild-to-severe exercise intolerance which was not affected by acute $\beta$ blocker withholding $\left(\mathrm{V}^{\prime} \mathrm{O}_{2} / \mathrm{kg}\right.$ peak, $15.6 \pm 2.8$ vs. 16.0 \pm 2.7 ; Table 2). We were satisfied that the reduced exercise performance in our CHF patients was not the result of reduced motivational effort: under both conditions, patients reported intolerable exertional symptoms at the peak of exercise and showed an RER $>1.0$ at peak exercise.

During exercise, $\mathrm{V}^{\prime}{ }_{\mathrm{E}}$ was higher at peak (by $3.5 \mathrm{~L} / \mathrm{min}, P=$ .04) and at maximal $\mathrm{P}_{\mathrm{ET}} \mathrm{CO}_{2}$ (by $2.2 \mathrm{~L} / \mathrm{min}, P=.002$ ), and $\mathrm{V}^{\prime}{ }_{\mathrm{E}} / \mathrm{V}^{\prime} \mathrm{CO}_{2}$ slope was steeper $(30.8 \pm 7.4$ vs. $29.1 \pm 5.4, P$ $=.04)$ in $\mathrm{CHF}$ patients after acute $\beta$-blocker withholding (Fig, 1). We considered the following potential contributors to reduced ventilatory efficiency after acute $\beta$-blocker withholding: 1) early local metabolic acidosis, reflecting reduced 


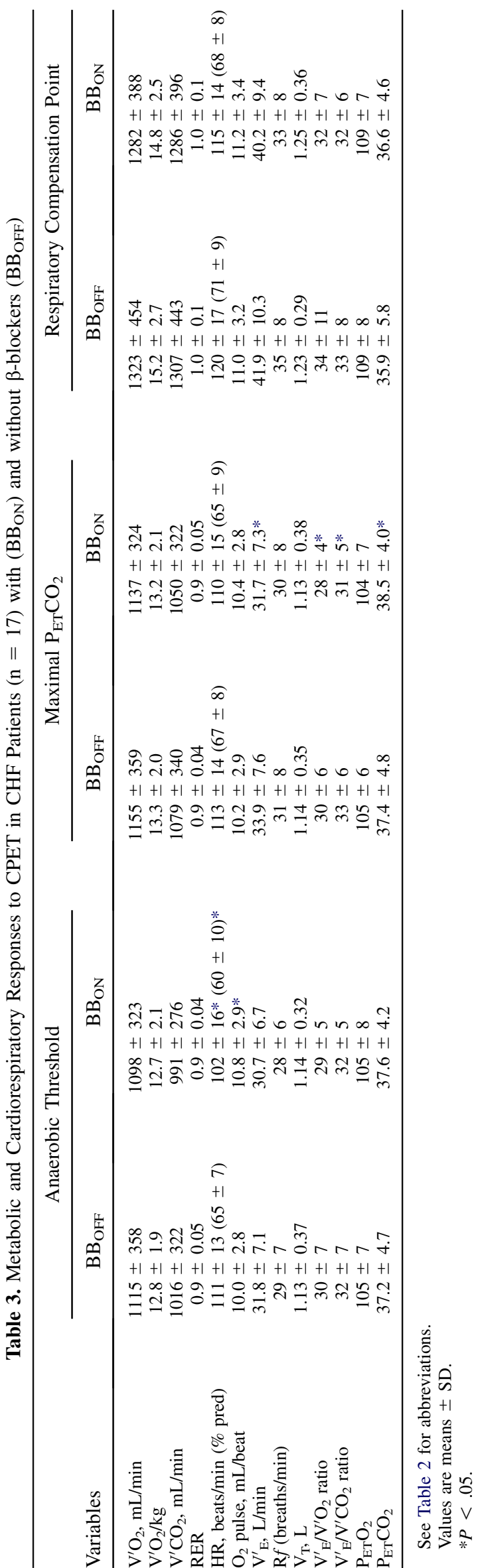

oxygen delivery/utilization; 2) increased ventilation/perfusion mismatching, reflecting reduced cardiac output or increased central venous distension/congestion; 3) decrease in $\mathrm{CO}_{2}$ set point, caused by the reversion to the overactive chemo- and metabo- and ergo- reflexes, which are driven by the sympathetic nervous system activity; or 4) a combination of these.

In the current study, acute $\beta$-blocker withholding did not delay the occurrence of the anaerobic threshold and $\mathrm{V}^{\prime} \mathrm{O}_{2}$ and $\mathrm{V}_{\mathrm{E}}^{\prime}$ measured at this point (Table 3) were not different between the 2 conditions, suggesting that the reduced ventilatory efficiency was unlikely to be related to an early local metabolic acidosis that, in turn, would have reflected a reduced oxygen delivery/utilization to the peripheral exercising muscles.

One possible explanation for our findings may lie in the pulmonary vasodilatory effect of $\beta$-blocker, especially carvedilol, because of its $\alpha$-blocking properties (14 of 17 patients were on carvedilol). ${ }^{23}$ Upon withdrawal, pulmonary vasoconstriction may occur; therefore, pulmonary perfusion may decrease, leading to a ventilation/perfusion mismatching, which would in turn increase the $\mathrm{V}^{\prime}{ }_{\mathrm{E}}^{\prime}$ $\mathrm{V}^{\prime} \mathrm{CO}_{2}$ slope. ${ }^{6,7,17,24}$ However, it should be noted that acute $\beta$-blocker withholding was associated with consistent increase in $\mathrm{V}^{\prime}{ }_{\mathrm{E}} / \mathrm{V}^{\prime} \mathrm{CO}_{2}$ slope in the absence of any measurable deterioration in pulmonary gas exchange; both $\mathrm{P}_{\mathrm{ET}} \mathrm{O}_{2}$ and $\mathrm{P}_{\mathrm{ET}} \mathrm{CO}_{2}$ were preserved at rest, at $A T$, at $R C$ and at peak exercise (Tables 2, 3). The $\mathrm{V}_{\mathrm{E}}^{\prime} / \mathrm{V}^{\prime} \mathrm{O}_{2}$ and $\mathrm{V}_{\mathrm{E}}^{\prime} / \mathrm{V}^{\prime} \mathrm{CO}_{2}$ ratios were also not different throughout exercise under the 2 conditions (Tables 2,3), thus suggesting that the increased ventilatory requirement observed after acute $\beta$-blocker withholding was less likely to reflect the increased ventilation/perfusion mismatching as a result of reduced ability to decrease a higher physiological dead space during exercise due to reduced pulmonary perfusion. Of note, $\mathrm{V}_{\mathrm{T}}$ expansion during exercise did not differ under both conditions, thus being unlikely that $\mathrm{V}_{\mathrm{T}}$ could also have contributed to the high physiological dead space (Tables 2,3 ). ${ }^{17}$

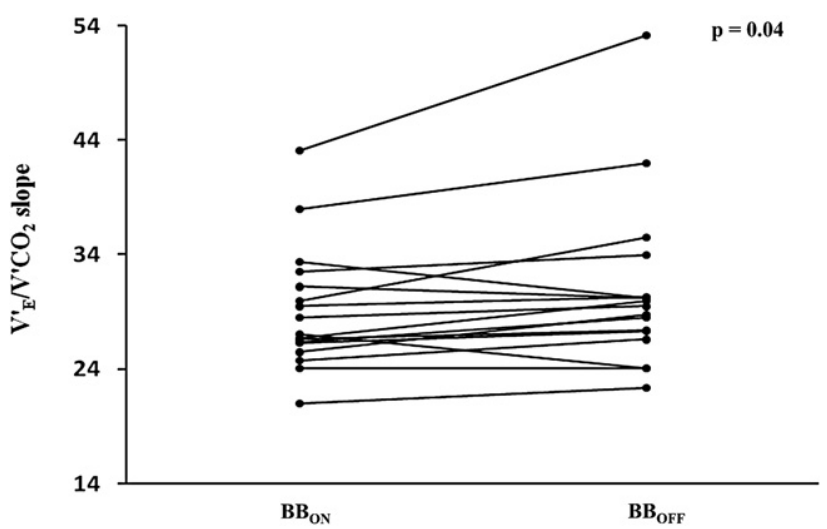

Fig. 1. Individual ventilation $\left(\mathrm{V}^{\prime}{ }_{\mathrm{E}}\right)$ and carbon dioxide production $\left(\mathrm{V}^{\prime} \mathrm{CO}_{2}\right)$ slopes $\left(\mathrm{V}_{\mathrm{E}}^{\prime} / \mathrm{V}^{\prime} \mathrm{CO}_{2}\right.$ slopes) are shown in all patients during $\mathrm{BB}_{\mathrm{OFF}}\left(27\right.$ hours after the last $\beta$-blocker ingestion) and $\mathrm{BB}_{\mathrm{ON}}$ ( 3 hours after administration of $\beta$-blocker) conditions. 

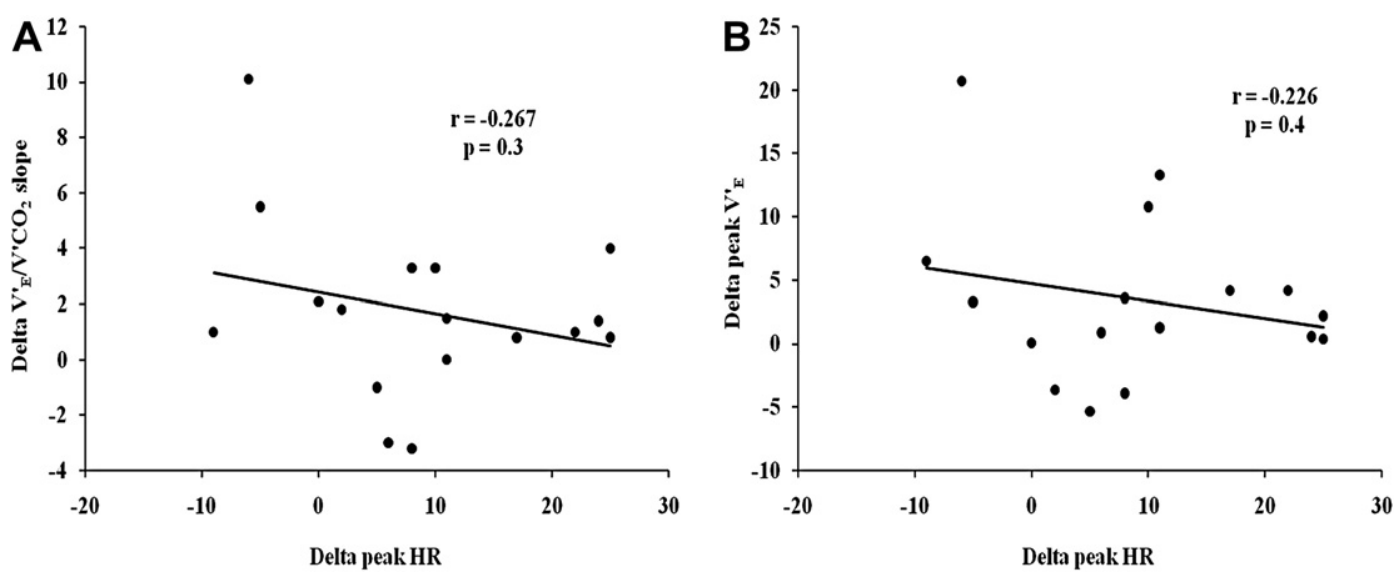

Fig. 2. (A) Correlation between the difference (delta) in peak heart rate (HR) between $\mathrm{BB}_{\mathrm{OFF}}(27$ hours after the last $\beta$-blocker ingestion) and $\mathrm{BB}_{\mathrm{ON}}\left(3\right.$ hours after administration of $\beta$-blocker) and delta in ventilation $\left(\mathrm{V}_{\mathrm{E}}^{\prime}\right)$ and carbon dioxide production $\left(\mathrm{V}^{\prime} \mathrm{CO}_{2}\right)$ slope $\left(\mathrm{V}^{\prime}{ }_{\mathrm{E}}^{\prime}\right.$ $\mathrm{V}^{\prime} \mathrm{CO}_{2}$ slope) between $\mathrm{BB}_{\mathrm{OFF}}$ and $\mathrm{BB}_{\mathrm{ON}}(r=-0.267, P=.3)$ in our 17 chronic heart failure $(\mathrm{CHF})$ patients (filled circles). (B) Correlation between delta in peak $\mathrm{HR}$ between $\mathrm{BB}_{\mathrm{OFF}}$ and $\mathrm{BB}_{\mathrm{ON}}$ and delta in peak $\mathrm{V}_{\mathrm{E}}^{\prime}$ between $\mathrm{BB}_{\mathrm{OFF}}$ and $\mathrm{BB}_{\mathrm{ON}}(r=-0.226, P=.4)$ in our $17 \mathrm{CHF}$ patients (filled circles).

The steepness with which $\mathrm{V}_{\mathrm{E}}^{\prime}$ rises with respect to $\mathrm{V}^{\prime} \mathrm{CO}_{2}$ is also determined by the behavior of arterial $\mathrm{CO}_{2}$ tension and the $\mathrm{V}^{\prime} \mathrm{CO}_{2}$ during exercise. Having reasonably excluded the previously mentioned mechanisms and given that acute $\beta$-blocker withholding did not modify the $\mathrm{V}^{\prime} \mathrm{CO}_{2}$ throughout exercise in our study, we can infer that the slope of the $\mathrm{V}_{\mathrm{E}}^{\prime} / \mathrm{V}^{\prime} \mathrm{CO}_{2}$ relationship would have substantially increased if $\mathrm{PaCO}_{2}$ was driven down by a high ventilatory drive from overactive peripheral chemoreceptors or by overactive metabo- or ergoreceptors in exercising skeletal muscles. The $\mathrm{CO}_{2}$ set point can be noninvasively estimated by the $\mathrm{P}_{\mathrm{ET}} \mathrm{CO}_{2}$ during exercise before the metabolic compensation point is reached. This point, that we called maximal $\mathrm{P}_{\mathrm{ET}} \mathrm{CO}_{2}$, is the highest value of $\mathrm{P}_{\mathrm{ET}} \mathrm{CO}_{2}$ recorded during an incremental exercise test, and was observed between the $A T$ and the $R C$ point when the $\mathrm{P}_{\mathrm{ET}}$ $\mathrm{CO}_{2}$ remains constant (Table 3). The observation that after acute $\beta$-blocker withholding the recorded maximal $\mathrm{P}_{\mathrm{ET}} \mathrm{CO}_{2}$ was $1.1 \mathrm{~mm} \mathrm{Hg}$ lower $(P=.03)$ and $\mathrm{V}_{\mathrm{E}}^{\prime}$ was $2.2 \mathrm{~L} / \mathrm{min}$ higher $(P=.002)$ with an unchanged $\mathrm{V}^{\prime} \mathrm{CO}_{2}$ (Table 3$)$ strongly favors a decrease in $\mathrm{CO}_{2}$ set point, likely from an increased excitatory inputs on $\mathrm{V}^{\prime}{ }_{\mathrm{E}}$ caused by the restoration of the overactive chemo- and metabo- and ergoreflexes, which are driven by the sympathetic nervous system activity. ${ }^{25-28}$

The contention that acute $\beta$-blocker withholding exerted its effect more on chemo-, metabo-, or ergo-receptors rather than on $\beta_{1}$-blockade, is also supported by the lack of correlation between delta peak HR (an excellent in vivo measure of $\beta$-blockade ${ }^{22}$ ) and either delta peak $\mathrm{V}_{\mathrm{E}}^{\prime}$ or delta $\mathrm{V}_{\mathrm{E}}^{\prime} / \mathrm{V}^{\prime} \mathrm{CO}_{2}$ slope (Fig. 2). Comparison of our data on acute (24-hour) $\beta$-blocker withholding with historical data kindly provided by Agostoni and colleagues (Fig. 1, Group B, from reference 7) on chronic (2-month) $\beta$-blocker withholding suggests the
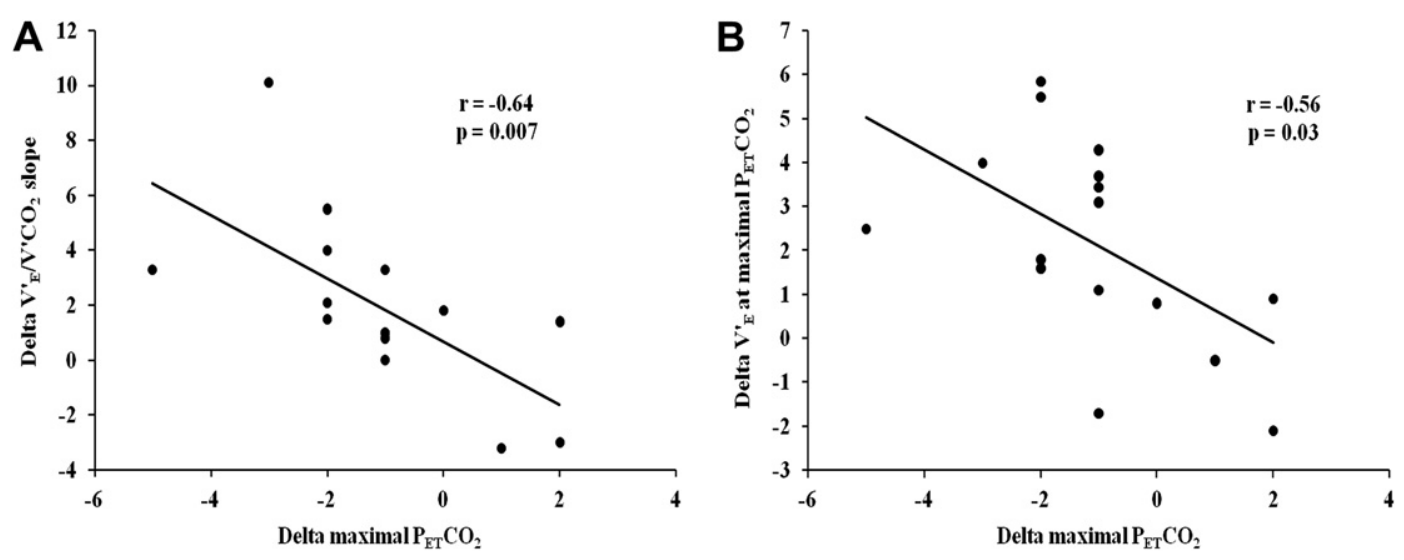

Fig. 3. (A) Correlation between the difference (delta) in end-tidal partial pressure for carbon dioxide $\left(\mathrm{P}_{\mathrm{ET}} \mathrm{CO}_{2}\right)$ between $\mathrm{BB}$ OFF $(27$ hours after the last $\beta$-blocker ingestion) and $\mathrm{BB}_{\mathrm{ON}}\left(3\right.$ hours after administration of $\beta$-blocker) measured at maximal $\mathrm{P}_{\mathrm{ET}} \mathrm{CO}_{2}$ and delta in ventilation $\left(\mathrm{V}_{\mathrm{E}}^{\prime}\right)$ and carbon dioxide production $\left(\mathrm{V}^{\prime} \mathrm{CO}_{2}\right)$ slope $\left(\mathrm{V}_{\mathrm{E}}^{\prime} / \mathrm{V}^{\prime} \mathrm{CO}_{2}\right.$ slope $)$ between $\mathrm{BB}_{\mathrm{OFF}}$ and $\mathrm{BB}_{\mathrm{ON}}(r=-0.64, P=.007)$ in our 17 chronic heart failure (CHF) patients (filled circles). (B) Correlation between delta in $\mathrm{P}_{\mathrm{ET}} \mathrm{CO}_{2}$ between $\mathrm{BB}_{\mathrm{OFF}}$ and $\mathrm{BB}_{\mathrm{ON}}$ and delta in $\mathrm{V}^{\prime} \mathrm{E}$ between $\mathrm{BB}_{\mathrm{OFF}}$ and $\mathrm{BB}_{\mathrm{ON}}$ both measured at maximal $\mathrm{P}_{\mathrm{ET}} \mathrm{CO}_{2}(r=-0.56, P=.03)$ in our 17 CHF patients (filled circles). 

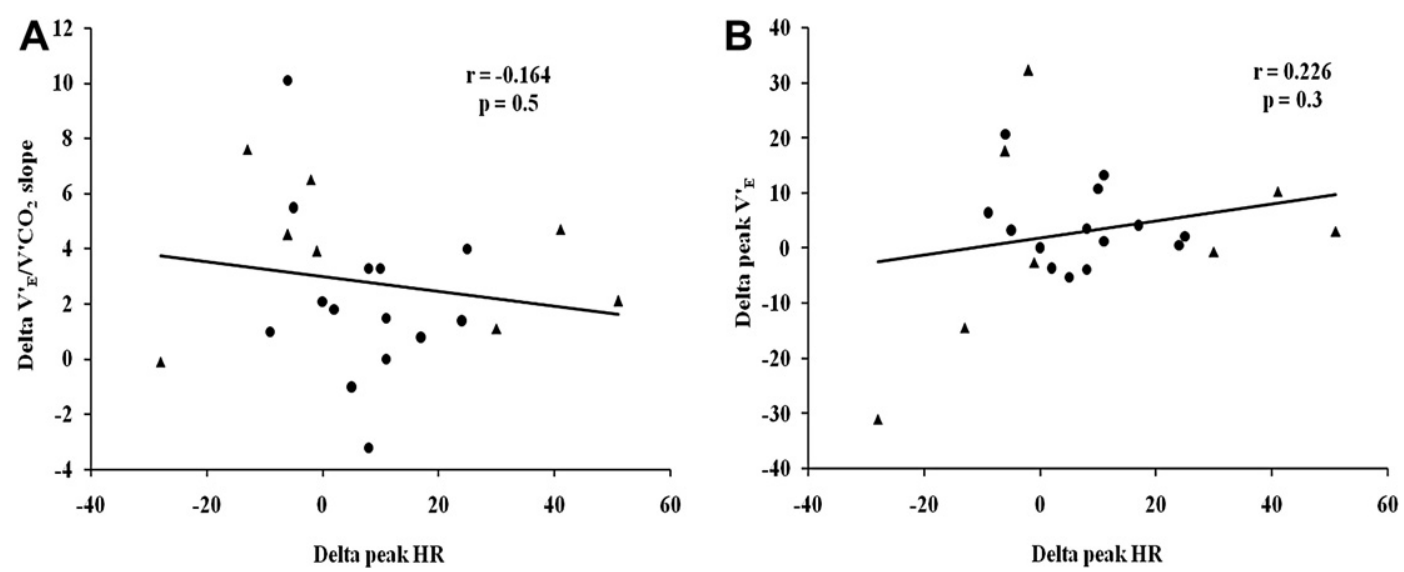

Fig. 4. (A) Correlation between delta in peak heart rate (HR) between $\mathrm{BB}_{\mathrm{OFF}}\left(27\right.$ hours after the last $\beta$-blocker ingestion) and $\mathrm{BB}_{\mathrm{ON}}(3$ hours after administration of $\beta$-blocker) and delta in ventilation $\left(\mathrm{V}_{\mathrm{E}}^{\prime}\right)$ and carbon dioxide production $\left(\mathrm{V}^{\prime} \mathrm{CO}_{2}\right)$ slope $\left(\mathrm{V}_{\mathrm{E}}^{\prime} / \mathrm{V}^{\prime} \mathrm{CO}_{2}\right.$ slope $)$ between $\mathrm{BB}_{\mathrm{OFF}}$ and $\mathrm{BB}_{\mathrm{ON}}(r=-0.164, P=.5)$ in our 14 chronic heart failure (CHF) patients on carvedilol (filled circles) pooled with the $8 \mathrm{CHF}$ patients on carvedilol from Agostoni ${ }^{7}$ (filled triangles). (B) Correlation between delta in peak $\mathrm{HR}_{\text {between }} \mathrm{BB}_{\mathrm{OFF}}$ and $\mathrm{BB}_{\mathrm{ON}}$ and delta in peak $\mathrm{V}_{\mathrm{E}}^{\prime}$ between $\mathrm{BB}_{\mathrm{OFF}}$ and $\mathrm{BB}_{\mathrm{ON}}(r=0.226, P=.3)$ in our $14 \mathrm{CHF}$ patients on carvedilol (filled circles) pooled with the $8 \mathrm{CHF}$ patients on carvedilol from Agostoni $^{7}$ (filled triangles).

same mechanisms and interpretations (Fig. 4), ie, that the decreased ventilatory efficiency is likely from an increase of $\mathrm{V}^{\prime} \mathrm{CO}_{2}$-independent regulation of $\mathrm{V}_{\mathrm{E}}^{\prime}$.

\section{Limitations}

The number of patients of the present study is limited; therefore, we must be very circumspect in any generalization of our findings to the larger $\mathrm{CHF}$ population. The lack of measurement of central hemodynamics and $\mathrm{PaCO}_{2}$ during exercise precludes a definitive assessment of the effect of acute (24-hour) $\beta$-blocker withholding on ventilation/perfusion mismatching and on regulation of $\mathrm{CO}_{2}$ set point during exercise. Our use of unpublished data to evaluate a unified mechanism is somewhat unusual. However, we feel it is acceptable as the unpublished data derive from a previously published $\operatorname{study}^{7}$ and 1 of the authors participated in the current study and can vouch for the similarity of experimental conditions and data collection as the present study. ${ }^{7}$ We believe the use of these data is reasonable with the caveat that interpretation to the larger heart failure population should be made with caution. Further studies that contain a larger sample size and engage measurement of central hemodynamics and $\mathrm{PaCO}_{2}$ during exercise will be required to definitively elucidate the physiological mechanisms of the decreased ventilatory efficiency after $\beta$-blocker withholding.

\section{Conclusion}

The current study extends previous studies on the physiological mechanisms of $\beta$-blocker efficacy by exploring the interaction between the ventilatory efficiency and ventilation/perfusion mismatching and regulation of $\mathrm{CO}_{2}$ set point during exercise. Our results suggest that both acute and chronic $\beta$-blocker withholding produce decreased ventilatory efficiency, mostly from an increase of $\mathrm{V}^{\prime} \mathrm{CO}_{2}$-independent regulation of $\mathrm{V}_{\mathrm{E}}^{\prime}$ and less likely from a change in ventilation/perfusion mismatching. Further studies are required to determine the clinical implications of the pharmacologically induced interactions that we have described.

\section{Disclosures}

None.

\section{References}

1. Reindl I, Wernecke K, Opitz C, Wensel R, König D, Dengler T, et al. Impaired ventilatory efficiency in chronic heart failure: possible role of pulmonary vasoconstriction. Am Heart J 1998;136:778-85.

2. Clark AL, Volterrani M, Swan JW, Coats AJ. The increased ventilatory response to exercise in chronic heart failure: relation to pulmonary pathology. Heart 1997;77:138-46.

3. Kleber FX, Vietzke G, Wernecke KD, Bauer U, Opitz C, Wensel R, et al. Impairment of ventilatory efficiency in heart failure: prognostic impact. Circulation 2000;101:2803-9.

4. Clark AL, Volterrani M, Swan JW, Coats AJ. Ventilation-perfusion matching in chronic heart failure. Int J Cardiol 1995;48:259-70.

5. Guazzi M, De Vita S, Cardano P, Barlera P, Guazzi MD. Normalization for peak oxygen uptake increases the prognostic power of the ventilatory response to exercise in patients with chronic heart failure. Am Heart J 2003;146:542-8.

6. Kataoka M, Satoh T, Yoshikawa T, Nakamura I, Kohno T, Yoshizawa A, et al. Comparison of the effects of carvedilol and metoprolol on exercise ventilatory efficiency in patients with congestive heart failure. Circ J 2008;72:358-63.

7. Agostoni P, Guazzi M, Bussotti M, De Vita S, Palermo P. Carvedilol reduces the inappropriate increase of ventilation during exercise in heart failure patients. Chest 2002;122:2062-7. 
8. Witte KK, Thackray SD, Nikitin NP, Cleland JG, Clark AL. The effects of alpha and beta blockade on ventilatory responses to exercise in chronic heart failure. Heart 2003;89:1169-73.

9. Hall SA, Cigarroa CG, Marcoux L, Risser RC, Grayburn PA, Eichhorn EJ. Time course of improvement in left ventricular function, mass and geometry in patients with congestive heart failure treated with beta-adrenergic blockade. J Am Coll Cardiol 1995;25: 1154-61.

10. Waagstein F, Caidahl K, Wallentin I, Bergh C-H, Hjalmarson A. Longterm $\beta$-blockade in dilated cardiomyopathy. Effects of short- and longterm metoprolol treatment followed by withdrawal and readministration of metoprolol. Circulation 1989;80:551-63.

11. Gilbert EM, Abraham WT, Olsen S, Hattler B, White M, Mealy P, et al. Comparative hemodynamic, left ventricular functional, and antiadrenergic effects of chronic treatment with metoprolol versus carvedilol in the failing heart. Circulation 1996;94:2817-25.

12. Bristow MR. Pathophysiologic and pharmacologic rationales for clinical management of chronic heart failure with beta-blocking agents. Am J Cardiol 1993;71:C12-22.

13. Hall JA, Petch MC, Brown MJ. In vivo demonstration of cardiac beta 2 -adrenoreceptor sensitization by beta 1-antagonist treatment. Circ Res 1991;69:959-64.

14. Heilbrunn SM, Shah P, Bristow MR, Valantine HA, Ginsberg R, Fowler MB. Increased $\beta$-receptor density and improved hemodynamic response to catecholamine stimulation during long-term metoprolol therapy in heart failure from dilated cardiomyopathy. Circulation 1989;79:483-90.

15. MERIT-HF Study Group. Effect of metoprolol CR/XL in chronic heart failure: Metoprolol CR/XL Randomized Intervention Trial in Congestive Heart Failure (MERIT-HF). Lancet 1999;353:2001-7.

16. The Carvedilol Prospective Randomized Cumulative Survival (COPERNICUS) Study Group. Effect of carvedilol on survival in severe chronic heart failure. N Engl J Med 2001;344:1651-8.

17. Laveneziana P, O’Donnell DE, Ofir D, Agostoni P, Padeletti L, Ricciardi G, et al. Effect of biventricular pacing on ventilatory and perceptual responses to exercise in patients with stable Chronic Heart Failure. J Appl Physiol 2009;106:1574-83.
18. Wasserman K, Hansen JE, Sue DY, Casaburi R, Whipp BJ. Principles of exercise testing and interpretation. 3rd ed. Baltimore (MD): Lippincott Williams \& Wilkins; 1999.

19. Weber KT, Janicki JS. Cardiopulmonary exercise testing for evaluation of chronic cardiac failure. Am J Cardiol 1985;55:22A-31A.

20. Weber KT, Janicki JS, McElroy PA. Determination of aerobic capacity and the severity of chronic cardiac and circulatory failure. Circulation 1987;76:VI40-5.

21. Arena R, Myers J, Abella J, Peberdy MA, Bensimhon D, Chase P, et al. Development of a ventilatory classification system in patients with heart failure. Circulation 2007;115:2410-7.

22. Billeh R, Hirsh D, Barker C, Jorgensen B, Jeger R, Ramanathan K, et al. Randomized, double-blind comparison of acute beta1-blockade with $50 \mathrm{mg}$ metoprolol tartrate vs. $25 \mathrm{mg}$ carvedilol in normal subjects. Congest Heart Fail 2006;12:254-7.

23. DasGupta P, Broadhurst P, Lahiri A. The effects of intravenous carvedilol, a new multiple action vasodilatory beta-blocker, in congestive heart failure. J Cardiovasc Pharmacol 1991;18:S12-6.

24. Wasserman K, Zhang YY, Gitt A, Belardinelli R, Koike A, Lubarsky L, et al. Lung function and exercise gas exchange in chronic heart failure. Circulation 1997;96:2221-7.

25. Ponikowski P, Francis DP, Piepoli MF, Davies LC, Chua TP, Davos $\mathrm{CH}$, et al. Enhanced ventilatory response to exercise in patients with chronic heart failure and preserved exercise tolerance: marker of abnormal cardiorespiratory reflex control and predictor of poor prognosis. Circulation 2001;103:967-72.

26. Chua TP, Clark AL, Amadi AA, Coats AJ. Relation between chemosensitivity and the ventilatory response to exercise in chronic heart failure. J Am Coll Cardiol 1996;27:650-7.

27. Ponikowski P, Chua TP, Piepoli M, Ondusova D, Webb-Peploe K, Harrington D, et al. Augmented peripheral chemosensitivity as a potential input to baroreflex impairment and autonomic imbalance in chronic heart failure. Circulation 1997;96:2586-94.

28. Piepoli M, Clark AL, Volterrani M, Adamopoulos S, Sleight P, Coats AJ. Contribution of muscle afferents to the hemodynamic, autonomic, and ventilatory responses to exercise in patients with chronic heart failure: effects of physical training. Circulation 1996;93:940-52. 